\title{
Satisfaction Level of School Residents in Implementing A Child Safety System in School
}

\author{
Evi Widowati ${ }^{1}$, Herry Koesyanto ${ }^{2}$, Sugiharto ${ }^{3}$, Anik Setyo Wahyuningsih ${ }^{4}$, Eko Harjanto ${ }^{5}$ \\ \{eviwidowati@mail.unnes.ac.id ${ }^{1}$, dhim45ku@gmail.com ${ }^{2}$, giek.kribo@mail.unnes.ac.id ${ }^{3}$ \}
}

Universitas Negeri Semarang, Semarang, Indonesia ${ }^{1,2,3}$

\begin{abstract}
School is one of the places that are vulnerable to safety hazards because school penguins are dominated by children who do not have adequate safety knowledge and tend to panic easily when a disaster occurs. Therefore, the implementation of the safety system, especially for children in schools, is needed to reduce the emergence of injuries and other losses. The purpose of this study was to assess the level of satisfaction of school residents with the implementation of child safety systems. This study used a survey research. The sampling technique used was purposive sampling, coming from student representatives, parents, and school representatives. The results showed that only $48.80 \%$ of school residents were satisfied with the child's safety system at school. Dissatisfaction is dominated by answers from parents' representatives, their reasons were dominated by the lack of fulfillment of school facilities/infrastructure and the unavailability of SOPs related to the safety aspects.
\end{abstract}

Keywords: school, safety system, satisfaction, assessment

\section{Introduction}

Indonesia is an archipelago country that prone to natural disasters, both prone to natural disasters such as thunderstorms, tropical cyclones, El Nino with drought, La Nina accompanied by floods and landslides, and also vulnerable to earthquake disasters, except Kalimantan [1]. A broader, more human-centered approach to disaster prevention is very important. Disaster risk reduction practices must be multi-hazard and multisectoral, inclusive, and easily accessible to be efficient and effective. The need for collaboration with the public, private sector, civil society organizations, academics, and scientific and research institutions is becoming increasingly apparent to integrate disaster risk into their management practices [2].

Disasters impact physical, psychological, and social aspects, where the impact of disasters on children is far greater than of the adults. Preparedness through teachers is one of the best ways to prepare children for the psycho-social consequences of disasters [3] including digital-based safety education learning, so that class teacher will become more familiar with emergency protocols and able to manage emergency event procedures in the event of an actual disaster [4].

Modern schools are schools that focus a lot on school safety and security, both against external and internal threats in the school [5]. However, in reality, there are still many safety and security problems in schools. The main safety issues in the school climate survey include 
teachers in schools, the compactness of school reform, involvement in school growth, school input, student perceptions, teacher-student relationships, safety and maintenance, administration, academic orientation to students, values student behavior, guidance, studentstudent relationships, parent-school-community relations, teaching management, student activities, justice, order and discipline, parent involvement, resource sharing, student interpersonal relationships, student-teacher relationships, achievement motivation, school development, general school climate, curriculum, achievement, teaching methods, teaching style, learning, personal needs, assessment, ethos/school factors, ethos/individual factors, support, careers, relationships, safety, respect for students, planning and action, the fairness of rules, clarity of rules, and student influence [6].

Creating safe and healthy conditions at work requires elements and principles of occupational safety and health. The elements are Personal Protective Equipment/PPE; a manual for using tools and/or hazard signals; the existence of rules and division of duties and responsibilities; the existence of a workplace that conforms to the standard Work Environment Requirements, such as a workplace that is sterile from dust, dirt, cigarette smoke, gas vapor, radiation, machine and equipment vibrations, noise, a safe workplace from electric current, adequate lighting, comfortable ventilation, and air circulation; work rules and codes of conduct; supporting physical and spiritual health at work; the existence of complete facilities and infrastructure in the workplace; and the awareness in maintaining occupational safety and health [7].

From the description above it can be seen that there are still many safety problems that exist in schools and the need for improvement efforts to create safe, healthy, and childfriendly school conditions. Therefore we need a baseline assessment that involves all elements in the school to assess the extent of their satisfaction with the implementation of the existing school safety system and identify safety problems that exist in the school so that later can be used as a basis for formulating a plan for continuous improvement.

From the above background, the purpose of this study is to assess the level of satisfaction of school residents with the implementation of a child's safety system in SD X.

\section{Methods}

This study used a survey research design with a cross-sectional approach. The sampling technique used was purposive sampling, with a total sample of 43 respondents from student representatives, parents of students/school committees, and school representatives consisting of principals, teachers, school staff, and security. Data analysis is presented in quantitative and qualitative descriptive terms.

This research was conducted at SD X Yogyakarta as one of the elementary schools located in one of the disaster-prone provinces in Indonesia.

\section{Results and discussion}

Of the 43 respondents, the study showed that $48.80 \%$ or 21 respondents were satisfied with the safety system in SD X, while $51.20 \%$ or 22 respondents felt dissatisfied with the existing safety system. In detail, the respondents' ratings are presented in Figure 1. 
Based on Figure 1. it shows that 14 children were satisfied with the safety system and 2 children were dissatisfied, 12 people from the school were satisfied with the safety system and 6 people were dissatisfied, and there was 1 committee who was satisfied with the safety system and 8 people were not satisfied.

Most respondents were satisfied with because of the existence of cooperation, responsibilities, and a good family system between the school, students, parents and security, which amounted to $38 \%$; the availability of some facilities and infrastructure that are safe for school residents, namely by $14 \%$; the availability of supporting safety facilities, for example, CCTV, portable fire extinguishers, and security by $14 \%$; and other answers by $34 \%$.

Salvation is a state of survival and free from danger. The situation of a school that is survived will produce a school culture that is responsive and optimizes social learning, emotional and cognitive development of students [8]. Satisfaction can lead to improving the quality of life of individuals [9]. One of the satisfaction levels of citizens depends on the extent of safety can be obtained [10]. School safety aspects do not only focus on mitigating violent incidents because schools have the potential to play an important role in preventing mental, emotional, student behavior, identifying and supporting students when experiencing mental health problems, and reducing violence in adolescents [11].

Besides learning places, schools are also workplaces. Policies on the work safety system can increase employee job satisfaction because employees feel safe and comfortable when in their work environment [12]. Job satisfaction is an individual thing, where every employee wants a guarantee of safety at work. The more safety aspects that are under the wishes of the employee, the higher the level of satisfaction that arises in the employee [13]. The work safety program affects employee job satisfaction, for example, safety socialization activities that are carried out periodically, this shows that the importance of employee safety in work is of high concern [14].

While the reasons for the dissatisfaction of the respondents of this study include: there are still some safety facilities and infrastructure that have not yet been fulfilled and are not childfriendly at 44\%; there is no clear SOP regarding child safety management by $30 \%$; the lack of supporting facilities for security and child safety by $13 \%$; lack of socialization and trained personnel to monitor child safety by $9 \%$; food safety and food security of children in schools have not been well monitored by $4 \%$.

Infrastructure which is very minimal and limited to be one of the reasons have not been maximized to implement the safety standards in schools [15]. The most important supporting infrastructure in the school is the emergency response team, which is available at all times [16], disaster prevention map [17], has more than one emergency evacuation area agreed and known to everyone [16].

Also, dissatisfaction can occur due to negligence that can result in the physical injuries suffered by students and teachers. The teacher has the task of caring for students and providing adequate supervision. Teachers must take extra care of students in playgrounds, sports fields, and in-class or when sightseeing. If there is negligence on the part of the teacher in maintaining the students, the school must be able to take responsibility for it. Negligence can also arise in the form of providing unsafe school equipment and environments. The higher the risk or potential for danger, the greater the task assigned to the teacher [18]. 


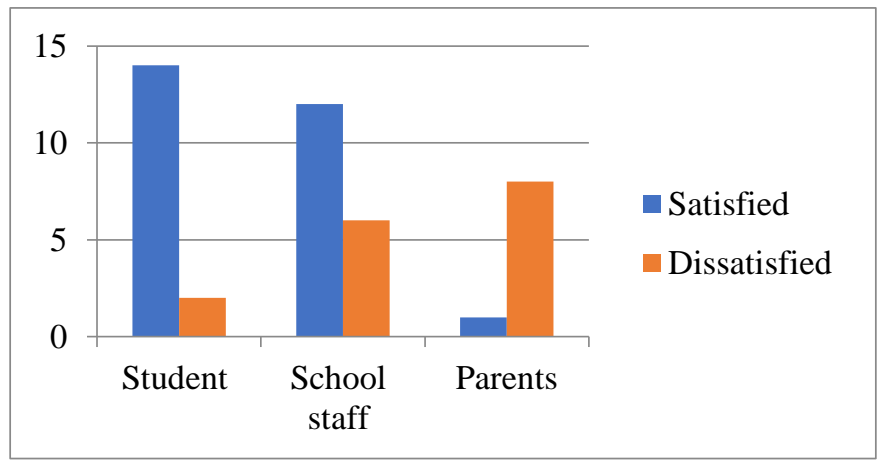

Fig. 1. School citizens' satisfaction with school safety systems evaluation

From the dissatisfaction, respondents gave some input to build a safety system in SD X, including $20 \%$ giving input on the consistent efforts in completing and monitoring infrastructure in schools; prepare and implement SOPs related to child safety and security systems by $22 \%$; provide training, outreach, and direction to all school residents by $20 \%$; increase cooperation and coordination with related parties to monitor child safety in schools by $16 \%$; the addition of security and safety support facilities by $8 \%$; conduct disaster response simulations, at least for natural disasters and fires in stages by $4 \%$. Other inputs include incorporating disaster-based school-based curriculum and the existence of foundation support in funding, program provision, and safety infrastructure in schools that are in line with child safety and friendly standards.

From the input of respondents, it can be seen that the majority of respondents provided input related to the preparation and implementation of SOPs for safety in schools. Systematic work procedures in carrying out tasks in the workplace are the most important factor in the occupational safety and health management system. A job requires guidance as a guide for officers to reduce the risk of an accident. Every worker needs to follow established work procedures. This is important to ensure the safety and health of these workers. The procedure is usually outlined in the form of Standard Operating Procedures (SOP) [19].

Safety procedure/SOP is a standard or procedure that can provide information to workers to carry out their duties and responsibilities safely and comfortably to avoid illness or accidents due to work, to achieve the goals set by a workplace [19].

SOP can provide convenience to every worker in carrying out their duties so that they can provide quality work results, in addition to avoiding the risk of exposure or contracting diseases that can arise from a particular job. Understanding, attitude, and awareness are important things that must be possessed by every employee in implementing and complying with SOP so that every worker can do his job properly and correctly [19].

Safety education is very much needed for elementary school children because not many students know about how mitigation efforts they have to do and from which sources of information related to disaster mitigation can be accessed, so knowledge about disaster mitigation must be included in the curriculum content in schools starting from elementary school level including activities in the laboratory to maintain the safety of students [20]. Besides, it was also strengthened by the provision of socialization that aims to increase the capacity of the community especially elementary school students so that from the beginning 
they can understand the importance of disaster mitigation to reduce the risk of loss due to disasters $[21,22]$.

On the other hand, knowledge and skills about disaster mitigation education are important to be mastered by the teacher, because in the classroom teachers must be able to equip students with theoretical knowledge and practical knowledge about education about disasters. The results showed that the average value of the basic knowledge of disasters owned by the teacher was good at 7.5. While the average value of the ability to assess the potential for disaster is 7.2 (included in the sufficient category) and the average value of attitude to respond to a disaster is 7.1 (included in the sufficient category) [23]. To overcome the existing limitations, a partnership or collaboration effort is needed, for example with the Local Health Office and Puskesmas (community health centers) for the preparation of the UKS (Indonesia: Unit Kesehatan Sekolah; English: School Healthcare Unit) program [24]. UKS is one of the strategic units in schools that can be integrated into disaster risk reduction activities.

Providing knowledge and education about disaster preparedness or emergency response to elementary school children and all staff in the school environment is one way to introduce early on to disaster response. Simulations or providing training are important to increase knowledge and speed of evacuation and can increase the enthusiasm and activeness of children in training or the provision of materials related to emergency response [25]. Also, training/simulation of emergency response in schools is a learning process carried out with systematic procedures to increase the knowledge of all school residents in dealing with disasters while increasing individual competencies related to safety aspects. Disaster preparedness training and simulation will be able to broaden students' and school insights in dealing with disasters and be able to take appropriate attitudes and actions when disaster strikes [26].

\section{Conclusion}

The conclusion in this study is that most school residents in SD X were not satisfied with the current safety system at the elementary school, it can be seen that $48.80 \%$ of school residents were satisfied with the child's safety system at school while $51.20 \%$ of respondents felt unsatisfied. Dissatisfaction was dominated by the answers from the parents' representatives, while answers to satisfaction with the safety system at school were dominated by answers from students. Reasons for dissatisfaction were dominated by the lack of fulfillment of school facilities and infrastructure and the unavailability of SOPs related to the safety aspects of children. From these results, it can be concluded that the majority of school residents felt unsatisfied with the application of the child safety system in the current school. The advice given is the fulfillment of child-friendly safety facilities and infrastructure in schools, preparation of SOPs, training, strengthening networks, and the application of safety grievance mechanisms for continuous improvement.

The limitation in this study is that the research data was taken when the COVID-19 pandemic occurred in 2020 so that the data was taken through an online network system either filling out questionnaires via Google Form, social media (whatsapp) or using other cell phone media. 


\section{Acknowledgments}

Implementation of this research was funded by the "Penelitian Unggulan Perguruan Tinggi 2020" as The Competitive Research Grant Scheme by Sport Science Faculty of Universitas Negeri Semarang. Thanks for the services, opportunities, and trust to Sport Science Faculty, Universitas Negeri Semarang.

\section{References}

[1] Nasional GTPPRB dalam SP. Strategi Pengarusutamaan Pengurangan Risiko Bencana Di Sekolah. Jakarta, Indonesia: Kementerian Pendidikan Nasional; 2010. p. 1-41.

[2] UN. Sendai Framework for Disaster Risk Reduction 2015-2030. In: The Third UN World Conference. Sendai, Japan: UNISDR; 2015. p. 1-37.

[3] Elangovan AR, Kasi S. Psychosocial Disaster Preparedness For School Children By Teachers. Int J Disaster Risk Reduct [Internet]. Elsevier; 2015;12:119-24. Available from: http://dx.doi.org/10.1016/j.ijdrr.2014.12.007

[4] Schmidt J. Notes on national earthquake education programs in Israel. Procedia Eng [Internet]. Elsevier Ltd; 2018;212:1265-72. Available from: https://doi.org/10.1016/j.proeng.2018.01.163

[5] Mowen TJ. School Safety [Internet]. 2nd Editio. Vol. 21, International Encyclopedia of the Social \& Behavioral Sciences: Second Edition. USA: Elsevier Ltd; 2015. 107-111 p. Available from: http://dx.doi.org/10.1016/B978-0-08-097086-8.45081-6

[6] Skiba R, Simmons AB, Peterson R, Forde S. The Handbook of School Violence and School Safety From Research to Practice. Jimerson SR, Furlong MJ, editors. London: Lawrence Erlbaum Associates, Publishers; 2006. 157-169 p.

[7] Ayu Er. Meytha Gayatri I. Hubungan Keselamatan dan Kesehatan Kerja (K3) dengan Kinerja Karyawan pada PT. UOB Indonesia Cabang Bengkulu. Ekombis Rev. 2015;3(2):185-96.

[8] Awang M, Suyanto N. Pendekatan keselamatan dan kesejahteraan pelajar untuk sekolah-sekolah di Malaysia. Manag Res J. 2017;7(1):139-53.

[9] 'Ulyani Mohd Najib N, Aini Yusof N, Zainul Abidin N. Student residential satisfaction in research universities. J Facil Manag. 2011;9(3):200-12.

[10] Husin HN, Nawawi AH, Ismail F, Khalil N. Correlation Analysis of Occupants' Satisfaction and Safety Performance Level in Low Cost Housing. Procedia - Soc Behav Sci [Internet]. Elsevier B.V.; 2015;168:238-48. Available from: http://dx.doi.org/10.1016/j.sbspro.2014.10.229

[11] Safety FCOS. School Safety. Washington, D.C.; 2018.

[12] Mardiana Yusuf R, Eliyana A, Novita Sari O. The Influence of Occupational Safety and Health on Performance with Job Satisfaction as Intervening Variables (Study on the Production Employees in PT. Mahakarya Rotanindo, Gresik). Am J Econ. 2012;136-40.

[13] Aldini RL, Afrianty TW. Pengaruh Sistem Manajemen Keselamatan dan Kesehatan Kerja (SMK3) terhadap Kepuasan Kerja serta Dampaknya terhadap Kinerja Karyawan (Studi pada Karyawan PT. INDOLAKTO Purwosari). J Adm Bisnis. 2019;72(1):212-21.

[14] Fajri K, Utami HN, Prasetya A. Pengaruh Program Keselamatan dan Kesehatan Kerja (K3) terhadap Kepuasan Kerja dan Kinerja Karyawan (Studi Pada Karyawan PT Brantas Abipraya (Persero) dalam Proyek Pembangunan Wisma Atlet Kemayoran). J Adm Bisnis. 2017;46(1):11-9.

[15] Ramadhan GT, Ismara KI. Pengaruh Pengetahuan dan Sarana Prasarana terhadap Karakter Siswa terkait Kesehatan dan Keselamatan Kerja Siswa. E-Journal Univ Negeri Yogyakarta. 2016;6(4):303-11.

[16] O'Connor P. Pedagogy of love and care: shaken schools respond. Disaster Prev Manag [Internet]. Emerald; 2013;22(5):425-33. Available from: https://doi.org/10.1108/DPM-10-2013-0176

[17] Chen C, Lee W. Damages to school infrastructure and development to disaster prevention education strategy after Typhoon Morakot in Taiwan. Disaster Prev Manag An Int J [Internet]. Emerald; 2012;21(5):541-55. Available from: https://doi.org/10.1108/09653561211278680

[18] Newnham H. When is a teacher or school liable in negligence? Aust $J$ Teach Educ. 2000;25(1):45-51. 
[19] Hariyono W, Awaluddin YF. Standar Operasional Prosedur (SOP) Aspek Keselamatan dan Kesehatan Kerja (K3) di Unit Sarana PT Kereta Api Indonesia (Persero) Daerah Operasi VI Yogyakarta. In: Seminar Nasional Teknik Industri Universitas Gadjah Mada. Yogyakarta: Program Studi Teknik Industri Universitas Gadjah Mada; 2016. p. 25-32.

[20] Hutasoit FE, Widowati E. Gambaran Penerapan Safety Education (Pendidikan Keselamatan) di Sekolah Dasar. J Heal Educ. 2017;2(1):66-72.

[21] Farida M, Alimuddin I, Maulana A, Irfan UR, Jaya A, Sultan, et al. Sosialisasi Bencana Geologi dan Mitigasinya di Sekolah Dasar Islam Terpadu (SDIT) Ar-Rahmah Makassar. TEPAT J Teknol Terap untuk Pengabdi Masy. 2019;2(2):66-73.

[22] Adnyani IAS, Seniari NM, Supriyatna, Natsir A, Nababan S, Ratnasari D. Keselamatan dan Kesehatan Kerja (K3) Laboratorium Siswa SMPN 7 Mataram. In: Seminar Nasional Pengabdian kepada Masyarakat. Mataram: LPPM Universitas Mataram; 2019. p. 170-4.

[23] Bashori I. Peran Guru terhadap Kesiapsiagaan Sekolah dalam Menghadapi Bencana Banjir di Kelurahan Sewu Kecamatan Jebres Kota Surakarta. Surakarta; 2013.

[24] Gurning FP, Daulay AJ. Pembinaan Puskesmas terhadap Pelaksanaan Program Usaha Kesehatan Sekolah di Wilayah Kerja Puskesmas Padang Matinggi Kota Padangsidimpuan. Jumantik. 2018;3(1):100-18

[25] Septiadi A. Perbedaan Sistem dan Pengetahuan Tanggap Darurat Bencana Kebakaran sebelum dan sesudah Pemberian Pelatihan pada Gedung Sekolah Dasar Sang Timur Semarang. J Kesehat Masy. 2012;1(2):635-43.

[26] Daud R, Sari SA, Milfayetty S, Dirhamsyah M. Penerapan Pelatihan Siaga Bencana dalam Meningkatkan Pengetahuan, Sikap, dan Tindakan Komunitas SMA Negeri 5 Banda Aceh. J Ilmu Kebencanaan Pascasarj Univ Syiah Kuala. 2014;1(1):26-34. 